\begin{tabular}{|c|c|c|}
\hline 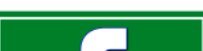 & Int.J.Curr.Microbiol.App.Sci (2021) 10(08): 629-635 & \\
\hline & $\begin{array}{l}\text { International Journal of Current Microbiology and Applied Sciences } \\
\text { ISSN: 2319-7706 Volume } \mathbf{1 0} \text { Number } 08 \mathbf{( 2 0 2 1 )} \\
\text { Journal homepage: } \underline{\text { http://www.ijcmas.com }}\end{array}$ & 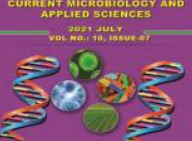 \\
\hline $\begin{array}{l}\text { EXCELLENT } \\
\text { PUBLISHERS }\end{array}$ & & \\
\hline
\end{tabular}

\title{
Effect of Cluster Front Line Demonstrations (CFLD) on Production, Profitability, and Social Impact on Mustard cultivation
}

\author{
Narender Kumar ${ }^{1 *}$, N. K. Yadav ${ }^{2}$ and Balbir Singh ${ }^{1}$ \\ ${ }^{1}$ Krishi Vigyan Kendra, Bawal, India \\ ${ }^{2}$ Regional Research Station, Bawal, India \\ *Corresponding author
}

\section{A B S T R A C T}

\section{Keywords}

Indian mustard, CFLD, Extension gap, Technology gap, Technology index

Article Info

Accepted:

25 July 2021

Available Online:

10 August 2021
The objectives of CFLD was to demonstrate the improved technologies among the farmers recommended by the State Agricultural Universities (SAUs) and the Indian Council of Agricultural Research (ICAR) Institutes so that it would improve the production and generate interest in the growing of oilseed crops which is losing importance due to stagnation in the yield faced by the farmers while executing the Cluster Frontline Demonstrations.(CFLDs). Krishi Vigyan Kendra, Kaithal conducted 150 cluster frontline demonstrations of Indian Mustard. Cluster Frontline Demonstration (CFLD) is one of the most powerful tools for transfer of technology. Keeping in view of an effective extension approach of CFLD for dissemination of improved varieties of Indian Mustard, an impact assessment of CFLDs conducted by KVK, Kaithal was assessed. The results were compared between CFLD plots \& control plots (Farmer Practice). The CFLD on Indian Mustard registered 35.0 percent higher yield over farmer's practice on an average. The highest yield (19.85 q ha1) was recorded in 2018-19 in CFLD with variety RH-0749, which was 39.78 per cent more yield over the farmers practice(14.20 qha1). Average extension gap was recorded 4.60 q ha1 and average technology gap was recorded 4.70q ha1. The technology index ranged from 17.35 per cent to 21.42 per cent. The results indicated that the cluster frontline demonstration made a good impact on the farming community of Kaithal district as they were motivated by the new agricultural technologies applied in the CFLD of Indian Mustard.

\section{Introduction}

India is endowed with a wide variety of agroclimates and soils that enable cultivation of variety of oilseed crops. In the agricultural economy of India, oilseeds are next only to food grains in terms of acreage, production and value. Oilseed production assumes great importance in India because of the huge gap in demand and supply which was resulted in import of vegetables oil worth millions of rupees every year. Among oilseed crops, rapeseed mustard is the third important group of oilseed crops in the world after Soybean 
and palm oil. Vegetable oil constitutes an important part of our daily diet being source of energy, essential fatty acids and aminomacids. In India Rapeseed-mustard crops comprises indigenously grown species, like brown sarson (Brassica rapa L. var. brown sarson), toria, (Brassica rapa L., var toria), black mustard (Brassica nigra), yellow sarson (Brassica rapa L., var yellow sarson), Indian mustard (Brassica juncea), and taramira (Eruca sativa/vesicaria), which have been grown since about 3,500 BC with exotic species like gobhi sarson (Brassica napus) and Ethiopian mustard or karan rai (Brassica carinata). (Annonymous, 2015). India rank first in total rapeseed mustard production. The major rapeseed mustard growing states in India are Rajasthan, Madhya Pradesh, Uttar Pradesh, Haryana, Punjab, West Bengal, Gujarat, Bihar and Assam occupies approximately $86.5 \%$ of total area which is 5.76 million hectare in the country and $91 \%$ of total production of 6.82 million tonnes. Among the nine oil seed crops grown in India rapeseed mustard contribute about one third of the oil to the country. This crops can be cultivated both rain fed as well as irrigated condition and fetches higher market value, thus add to the rural economy specially to marginal and small farmers.

Rapeseed mustard is annual rabi season oil seed crop. Though the crop is having the high quality of oil and meal and is widely adaptable to varied agro-climatic conditions, the area, production and productivity of rapeseedmustard in India have been varying each year due to various abiotic and biotic factors coupled with India's domestic price support program.

To enhance the production and productivity, Krishi Vigan Kendra Kaithal have conducted cluster frontline demonstration (CFLDs) under National Mission on Oilseed and Oil palm (NMOOP) funded by government of India. The Cluster Frontline demonstrations (150) were conducted on farmer's field to demonstrate the impact of improved variety and bed planting methods other crop management technology on mustard over four years during Rabi 2018-19 to 2019-20.

\section{Materials and Methods}

The study was conducted by Krishi Vigayan Kendra, Kaithal from 2018-19 to 2019-20 using two varieties of Indian mustard (Brassica juncea) var. RH-0749 and RH-725.

Maturity duration of RH-0749 variety is 146148 days, oil content 39.0-39.5\% and with potential yield $28.00 \mathrm{q} /$ ha released in the year 2013 by CCSHAU Hisar. Maturity duration of RH-725 variety is 136-143 days, with potential yield 26.00 q/ha. Seeds were procured from Chaudhary Charan Singh Haryana Agricultural University Hisar and distributed to the selected farmers. The objectives of the CFLDs was to find out gap between potential yield, demonstration yield, extension gap and technology index.

The CFLDs was conducted with selected farmers group of the district. The sowing was done in the first fortnight of October. The farmers were guided by scientists from Krishi Vigyan Kendra in every stage of the crop, with respect to optimum plant population, recommended dose of fertilizer, irrigation management and plant protection measures. The yield data were collected from both the demonstration and farmers practice by random crop cutting method. Qualitative data were converted into quantitative form and expressed in terms of per cent increase in yield calculated using following formula:

$\%$ increase in the yield: (Demonstration yield

- farmers yield/farmers yield) x 100

Technology gap

Potential yield - demonstration yield 
Extention gap

Demonstration yield - yield under farmer practice

Technology index (\%)

Potential yield - demonstration yield/potential yield) x 100

\section{Results and Discussion}

\section{Grain Yield}

It is apparent from the data presented in Table 1 that selected varieties of Indian mustard (RH-0749 and RH-725) have significant and beneficial effect on grain yield of mustard. Data indicated that maximum yield per hectare (19.85 q/ha) were found with variety RH-0749 in 2018-19 followed by farmer practice. Minimum values for these parameters were observed in farmer practice over all the experimental years. Similarly, data presented in Table 1 exhibit a beneficial response to variety RH-0749 and RH-725 that 21.4 per cent increase in yield during 2018-19, 15.90 per cent during 2019-20, 39.78 per cent during 2018-19 and 30.50 per cent during 2019-20 respectively. The average yield of the two years of demonstration for both the varieties was $18.30 \mathrm{q} /$ ha against the check variety under farmers practices $13.70 \mathrm{q} / \mathrm{ha}$.. Benefit cost ratio for the year 2018-19 was 1.86:1 \& 1.80:1 for the year 2019-20 against the farmer practice 1:60:1 for 2018-19 and 1:56:1 in 2019-20. Similarly all these parameters were calculated for the variety RH-0749 with the potential yield of $20.0 \mathrm{q} / \mathrm{ha}$ sown for the two years 2018-19 and 2019-20. The average yield of the year 2018-19 was $18.64 \mathrm{q} /$ ha sown for the two year 2018-19 and 2019-20. The average yield of the year 2018-19 was 18.64 / ha and it was maximum over variety RH-0749 (17.92 q ha-1) and farmer practice (13.70 q ha 1). This results clearly indicated that the higher average grain yield with bed planting method in demonstration plots over the years compare to local check due to knowledge and adoption of full package of practices i. e. improved variety e. i., RH-0749 and RH-725, sowing method and crop management technologies like timely sowing seed treatment use of balanced dose of fertilizer as well application of sulphur timely wed management need based plant protection etc.

The yield of mustard could be increased over the yield obtained under farmers practices (old variety, no use of the balanced dose of fertilizer untimely sowing and no control measure adopted for pest management) of mustard cultivation. The above findings are in similarity with the findings of Chauhan et al., (2006), and Singh,(2004) \& Kumpawat, (2004).

\section{Economics}

Data on economic returns presented in Table land revealed that demonstrated technology of improved variety of mustard (RH-0749 and RH-725) and their associated agronomical practices produced 85.52 per cent higher net return (Rs. 28817/-) over the exciting farmer practices (Rs. 15425/-). Benefit cost ratio of RH-0749 variety for the year 2018-19 was 2.59:1\&2.57:1 for the year 2019-20 against the check variety $1.70: 1$ for the 2015-16 and $1.17: 1$ in 2016-17. For motivating the farmers for acceptance of improved mustard varieties RH-0749 and RH-725, the front line demonstration were carried out at the farmer's field and data also indicated that 35.0 per cent higher yield was recorded in demonstrated field than the existing technologies adopted by the farmers. In case of benefit cost ratio maximum benefit cost ratio was observed with RH-0749 variety of mustard compared to variety RH-725 and farmer practice. The results revealed that improved mustard variety is able to produce, by itself, plant growth and yield that were higher compared to farmer practice. 
Table.1 Effect of Cluster Frontline Demonstrations on Yield and Economics of Indian Mustard.

\begin{tabular}{|c|c|c|c|c|c|c|c|c|c|c|c|c|c|c|c|}
\hline & \multirow[t]{2}{*}{ Year } & \multirow[t]{2}{*}{$\begin{array}{l}\text { No. of } \\
\text { farmers }\end{array}$} & \multirow{2}{*}{$\begin{array}{l}\text { Total } \\
\text { area } \\
\text { (ha.) }\end{array}$} & \multicolumn{2}{|c|}{ Yield (q./ha) } & \multirow{2}{*}{$\begin{array}{c}\% \text { in- } \\
\text { crease in } \\
\text { yield }\end{array}$} & \multicolumn{4}{|c|}{$\begin{array}{l}\text { Economics of demonstration } \\
\text { (Rs./ha) }\end{array}$} & \multicolumn{4}{|c|}{ Economics of Farmer Practice (Rs./ha) } & \multirow[t]{2}{*}{$\begin{array}{c}\text { Potentia } \\
\text { yield }\end{array}$} \\
\hline & & & & $\begin{array}{c}\text { Demo } \\
\text { nstrati } \\
\text { on }\end{array}$ & $\begin{array}{l}\text { Farmers } \\
\text { Practice }\end{array}$ & & $\begin{array}{c}\text { Gross } \\
\text { cost }\end{array}$ & $\begin{array}{l}\text { Gross } \\
\text { return }\end{array}$ & $\begin{array}{c}\text { Net } \\
\text { return }\end{array}$ & $\begin{array}{c}\mathrm{Bc} \\
\text { ration }\end{array}$ & $\begin{array}{c}\text { Gross } \\
\text { cost }\end{array}$ & $\begin{array}{l}\text { Gross } \\
\text { return }\end{array}$ & Net return & $\begin{array}{c}\mathrm{Bc} \\
\text { ration }\end{array}$ & \\
\hline \multirow[t]{2}{*}{$\begin{array}{l}\text { RH- } \\
\text { 0749 }\end{array}$} & $\begin{array}{c}2018- \\
19\end{array}$ & 66 & 30 & 19.85 & 15.16 & 30.93 & 27598 & 51400 & 23801 & 1.86: 1 & 26320 & 42336 & 16106 & $1.61: 1$ & 24.0 \\
\hline & $\begin{array}{c}2019- \\
20\end{array}$ & 75 & 30 & 17.58 & 14.58 & 20.57 & 27430 & 49448 & 22018 & 1.80:1 & 26520 & 41480 & 14960 & $1.56: 1$ & 24.0 \\
\hline \multirow[t]{2}{*}{$\begin{array}{l}\text { RH- } \\
725\end{array}$} & $\begin{array}{c}2018- \\
19\end{array}$ & 68 & 30 & 18.65 & 13.20 & 41.28 & 21600 & 55950 & 34350 & 2.59:1 & 20600 & 36600 & 16000 & 1.70:1 & 23.0 \\
\hline & $\begin{array}{l}2019- \\
20\end{array}$ & 75 & 30 & 16.50 & 12.33 & 33.81 & 21814 & 56114 & 34500 & $2.57: 1$ & 20490 & 35125 & 14635 & $1.17: 1$ & 23.0 \\
\hline $\begin{array}{c}\text { Aver } \\
\text { age }\end{array}$ & $\ldots$ & 70.50 & 30 & 18.14 & 13.82 & 31.65 & 24610 & 53228 & 28617 & $2.21: 1$ & 23482 & 38885 & 15425 & $1.51: 1$ & 23.5 \\
\hline
\end{tabular}


Table.2 Effect of Cluster Frontline Demonstrations on Technological gap, Extension gap and Technology index of Indian mustard.

\begin{tabular}{|c|c|c|c|c|c|}
\hline Parameter & \multicolumn{2}{|c|}{$\begin{array}{c}\text { Indian Mustard var. RH- } \\
0749\end{array}$} & \multicolumn{2}{|c|}{$\begin{array}{c}\text { Indian Mustard var. RH- } \\
725\end{array}$} & \multirow[t]{2}{*}{ Average } \\
\hline Year & 2018-19 & 2019-20 & 2018-19 & $2019-20$ & \\
\hline $\begin{array}{l}\text { \% Increase } \\
\text { in the yield }\end{array}$ & 30.93 & 20.57 & 41.28 & 33.81 & 31.65 \\
\hline $\begin{array}{l}\text { Technology } \\
\text { Gap }\end{array}$ & 4.15 & 6.42 & 4.35 & 6.50 & 5.35 \\
\hline $\begin{array}{c}\text { Extension } \\
\text { Gap }\end{array}$ & 4.69 & 3.0 & 5.45 & 4.17 & 4.33 \\
\hline $\begin{array}{l}\text { Technology } \\
\text { index }(\%)\end{array}$ & 17.29 & 26.75 & 18.91 & 28.26 & 22.80 \\
\hline
\end{tabular}

The highest growth and yield response were achieved with variety RH-0749. This positive performance of the variety might be due to production potential of the improved variety and adoption of scientific agronomical practices leads to improved nutrient availability to growing crop (Singh et al., 1999).

As the crop grown under irrigated condition, the beneficial effect of improved variety with scientific agronomic practices like nutrient management, weed management etc. results in greater and longer availability of nutrients as per demand of the crop. The similar findings were also reported by Shekhawat et al., (2012).

\section{Technological gap}

Consequently extension parameter was also calculated and given in the Table no $2 \mathrm{j}$. The technology gap for demonstrated plots were 4.15 and $6.42 \mathrm{q} / \mathrm{ha}$ with variety RH-0749 and $4.35 \& 6.50$ q/ ha with variety RH-725 during the years 2018-19 and 2019-20 and respectively (Chauhan and Singh 2004). On an average technology gap under two years of CFLD program were $5.35 \mathrm{q} /$ ha for the mustard cultivation in the district Kaithal. The technology gap observed may be attributed to dissimilarity in the crop management practices, soil fertility status and local climatic situation.

\section{Extension gap}

Extention gap of RH-749 variety were 4.69 and $3.0 \mathrm{q} / \mathrm{ha}$ during 2018-19 and 2019-20 respectively, and 5.45 and $4.17 \mathrm{q} /$ ha with variety RH-725 during 2018-19 and 2019-20 respectively. On an average extension gap under two years of CFLD experiment was $4.33 \mathrm{q}$ /ha of mustard cultivation which emphasized the need to educate the farmers through various extension means i..e. cluster front line demonstration for adoption of improved production and protection technologies, to revert the trend of wide extension gap. More and more use of latest production technologies with high yielding varieties will subsequently change this alarming trend of hurdle extension gap. The above finding are in similarity with the findings of Samui, et al., (2000).

\section{Technology index}

Data on technology index presented in Table 2. The technology index shows the feasibility of the demonstrated technology at the farmer's field. The technology index varied from 17.29 
to 28.26 per cent (Table 2). On an average technology index was observed 18.36 per cent with variety $\mathrm{RH}-0749$ and 22.35 per cent for the variety RH-725 during the four experimental years of mustard in the district Kaithal of Haryana which shows the efficacy of good performance of technical interventions. This will accelerate the adoption of demonstrated technical intervention to increase the yield performance of Indian mustard at farmer's field.

This study on Effect of Cluster Frontline Demonstration on Production, Profitability, and social impact on mustard cultivation was conducted to assess the average status of mustard production in district Kaithal of Haryana, average cost of cultivation, net return, benefit cost ratio, challenges faced by mustard farmer and to suggest agronomical and technical measures for higher mustard production. The main issue reported by the mustard growers was non recommended varieties for the area and poor quality of seed. The mustard in important commercial oils seed crop in Kaithal district, therefore its cultivation need to be enhanced, so the KVK Kaithal started the front line demonstration at farmer fields in entire district. In conclusion, cultivation of Rapeseed mustard with improved variety $\mathrm{RH}-0749$ and $\mathrm{RH}-725$ have higher yield in comparison to the farmer practices in all the year of the evaluation. With in these two varieties of Indian mustard variety RH-0749 performed very well in the Kaithal district in comparison to the variety RH-725.

In conclusion, the results signify that the production and productivity can be increased in oilseed production through cluster frontline demonstrations by motivating the farmers for the adoption of improved agro technologies which were demonstrated in the CFLD plots.
But additional extension work is required to decrease the gap between demand and supply. However, soil moisture availability, rainfall conditions, climatic observations, diseases infestation and change in the location are also responsible for disparity in the yield of the crop. Thus, technologies demonstrated under CFLDs were helpful to improve the production, productivity, farmers income as well as increase in area under mustard crop.

\section{References}

Agricultural statistics at a glance (2016). Government of India Ministry of Agriculture and Farmers welfare. Directorate of economics and Statistics.

Chauhan C. P. S. and Singh R. B. (2004). "' Mustard performs well even with saline irrigation." Indian Farming, 42:17-20.

Chauhan J. S., Singh K. H., and Kumar A. (2006). " Compendium of Rapeseed-mustard varieties notified in India," Directorate of Rapeseed-Mustard Research, Bharatpur Rajasthan, pp. 7-13.

Gangasaran and Giri G. (2012), Growth and yield of mustard as influenced by irrigation and plant population'.' Annals of Agricultural Research 7(1):68-74.

Kumpawat B. S. (2004). "'Integrated nutrient management for maize mustard cropping system. 'Indian Journal of Agronomy, 49:4-7.

Samul, S. K., Mitra, S., Roy, D. K., Mandal, A., K and Saha, D. (2000), Evaluation of front line demonstration on groundnut. Journal of the Indian Society of Costal Agriculture Research, 18(2):180-183.

Shekhawat K., Rathore S. S., Premi O. P., Kandpal B. K., and Chauhan J. S. (2012). Advances Agronomic Management of Indian Mustard (Brassica juncea (L) (zernj. Cosson) : Am Overview. International Journal of Agronomy 2012: 1-14.

Vision 2050 published by ICAR- DRMR in year 2015. 


\section{How to cite this article:}

Narender Kumar, N. K. Yadav and Balbir Singh. 2021. Effect of Cluster Front Line Demonstrations(CFLD) on Production, Profitability, and Social Impact on Mustard cultivation. Int.J.Curr.Microbiol.App.Sci. 10(08): 629-635. doi: https://doi.org/10.20546/ijcmas.2021.1008.073 